\title{
Monocyte, neutrophil, eosinophil and lymphocyte volume levels in multiple myeloma patients
}

\author{
Esma Menevse', (i) Abdullah Sivrikaya', () Mehmet Dagli², (i) Hamiyet Kose' \\ 'Department of Medical Biochemistry, Selcuk University, Faculty of Medicine, Konya, Turkey \\ ${ }^{2}$ Department of Internal Medicine Division of Hematology, Selcuk University, Faculty of Medicine, Konya, Turkey
}

\begin{abstract}
Objectives: Multiple myeloma (MM) is a malignant proliferation of monoclonal plasma cells in the blood that may also cause renal failure. The most frequent complications of $\mathrm{MM}$ are painful pathological fractures, anemia, hyperkalemia, renal failure and recurrent bacterial infections. Seen from this aspect, it is indicated that inflammation is a significant component of the neoplastic process.

Methods: The present study aims to evaluate the association of monocyte, neutrophil, eosinophil and leucocyte volume values in patients with MM as a retrospective study. Sixty patients with MM aged $64.5 \pm 11.2$ and 107 healthy control aged $64.9 \pm 10.3$ years who were admitted to the Polyclinic of Hematology in the Faculty of Medicine of the Selcuk University were included in this study.

Results: The monocyte, lymphocytes, neutrophil volume levels were significantly higher in patients as $175.62 \pm 8.06$; $95.05 \pm 6.08 ; 152.51 \pm 8.18$, respectively, compared with the control group $170.41 \pm 8.15 ; 89.78 \pm 4.92 ; 148.19 \pm 8.04$, respectively. The eosinophil volume levels were $157.5 \pm 22.4$ in the patients group and $157 \pm 17.3$ in the control group $(p=0.953)$ The findings obtained in this study suggest that monocyte, lymphocytes, neutrophil volume values except eosinophil volume may be used a potentially prognostic biomarker in patients with Multiple myeloma.

Conclusion: The present study aimed to evaluate a biomarker that is easily analyzed. This study suggests that monocyte, lymphocytes, neutrophil volume values except eosinophil volume may be used as a potentially prognostic biomarker in patients with Multiple myeloma. And also, monocyte, lymphocyte and neutrophil volume levels are significant parameters that can be applied lower in cost.
\end{abstract}

Keywords: Eosinophil, lymphocytes, multiple myeloma, monocyte, neutrophil, retrospective data

$\mathrm{M}$ ultiple Myeloma (MM) is a malignant plasma cell structure disorder that gives rise to approximately $10 \%$ hematological malignancy [1]. MM is malignant proliferation that still occurs as a result of the uncontrolled growth of white blood cell monoclonal plasma cells [2-4]. Bone ion or monoclonal protein in urine and/or serum is diagnosed by clonal plasma cells [5]. MM is mostly seen between the ages of 25-81, but it occurs more frequently in men than in women [6]. In patients with MM, the most common complications are kidney failure, anemia, painful pathological fractures, hyperkalaemia and recurrent bacterial infections [7, 8]. Patients with MM have a high amount of protein in their blood.

Antibody-producing plasma cells (immunoglobulin) can be expressed as cells that destroy the effects of immune reactions and pressurized), which has a significant role in the immune system, which balances the $T$ cell's responses to the tumor cells $[2,9]$. Monocytes are the precursors of dendritic cells (DC). Lymphocytes are significant in the destruction of the M-protein [10]. Neutrophils have a remarkable task in evaluating the susceptibility of cells to infection [11]. Eosinophils

Address for correspondence: Abdullah Sivrikaya, MD. Department of Medical Biochemistry, Selcuk University, Faculty of Medicine, Konya, Turkey Phone: +90 3322236320 E-mail: hamiyetkose94@gmail.com ORCID: 0000-0003-2956-5681

Submitted Date: October 15, 2019 Accepted Date: April 24, 2020 Available Online Date: October 06, 2020

${ }^{\circ}$ Copyright 2020 by International Journal of Medical Biochemistry - Available online at www.internationalbiochemistry.com OPEN ACCESS This work is licensed under a Creative Commons Attribution-NonCommercial 4.0 International License. 
(Eoz) has a remarkable task in assessing the survival, proliferation, and retention of malignant plasma cells in the bone marrow (BM) [12].

In MM, myeloid cells are often transformed into new tumor cells. Due to its biology, myeloid-derived suppressor cells (MDSC) are crucial in suppressing and epitomizing the effects of cancer immunotherapy. These cells are associated with neutrophils and monocytes [11]. Clinical significance in MM has rarely been investigated. In this study, we aimed to investigate the prognostic effects of neutrophil, lymphocyte, monocyte and eosinophil volumes in patients with MM according to data of retrospective.

\section{Materials and Methods}

Sixty patients with MM providing the criteria of the International Myeloma Working Group (IMWG) were included in the retrospective review of patient records. In the present study, 107 people with years and gender-matched healthy control were included.

This study was divided into two groups. Group 1 included 60 patients with MM aged $64.5 \pm 11.2$ years. Group 2 included 107 healthy control aged $64.9 \pm 10.3$ years. All the groups were composed of whom were admitted to the Polyclinic of Hematology in the Faculty of Medicine at the Selcuk University between 2017 February-February 2018. Patients who were taken steroids, anabolic hormones, beta two agonists were not included in this study because of effecting of Neutrophil levels. New markers were added to the CRAB (Hypercalcemia, Kidney Failure, Anemia, Bone Disease) findings of the multiple myeloma patients which described the myeloma requiring treatment included in our study as: 1- SLIM presence of over $60 \%$ clonal plasma cells in bone marrow, 2 - being above 100 of free light chain ratio (FLC ratio), 3-and the presence of more than $5 \mathrm{~mm}$ or greater focal lesions in the whole body MR. VCD (bortezomib, cyclophosphamide, dexamethasone) protocol was applied to suitable patients for autologous stem cell transplantation. No secondary cancer was detected in our patients. Healthy control group who were admitted to the Polyclinic of Hematology for any health problem and checkup. Monocyte Volume, Neutrophil Volume, Eosinophil Volume, and Lymphocyte Volume levels were measured with a Beckman Coulter LH-780 hematology analyzer in the laboratory of Medical Biochemistry of the Selcuk University.

\section{Statistical analysis}

Statistical analysis was performed using SPSS v16. Student's t-test and Mann-Whitney U-test were used parametric variables for Monocyte Volume (MO VOL), Neutrophil Volume (NEU VOL) and Lymphocyte Volume (LY VOL) and non-parametric variables for Eosinophil Volume (EO VOL). Data were expressed as $x \pm S D$. Results were considered statistically significant at $p<0.05$.

\section{Results}

As shown in Figure 1, the monocyte volume was higher in patients with MM (175.62 \pm 8.06$)$ according to healthy subjects

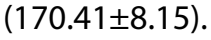

The levels of Lymphocyte Volume were $95.05 \pm 6.08$ in patients and $89.78 \pm 4.92$ in the healthy group (Fig. 2).

Neutrophil volume levels were significantly higher in patients as $152.51 \pm 8.18$ compared with the control group as $148.19 \pm 8.04$ (Fig. 3). The differences between the groups were significantly important according to the level of monocyte, lymphocyte and neutrophil volume levels.

However, eosinophil volume levels were 157.5 \pm 22.4 in the patients group and $157 \pm 17.3$ in the control group $(p=0.953)$ (Fig. 4). The differences between the groups were not important.

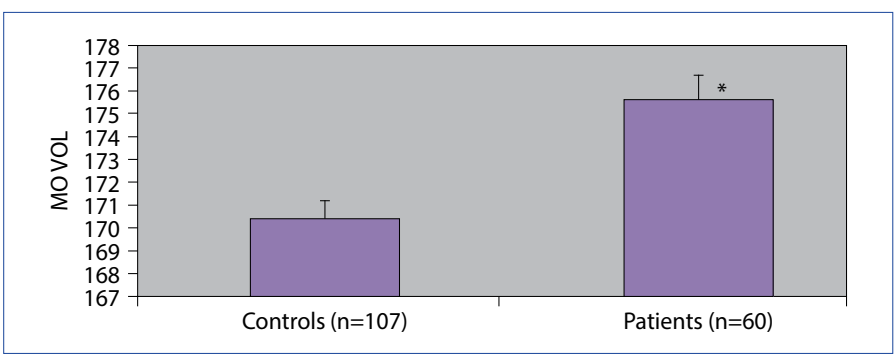

Figure 1. MO VOL in patients with multiple myeloma and control groups.

MO VOL: monocyte volume, patients $(175.62 \pm 8.06)$ according to healthy subjects (170.41 \pm 8.15$), p=0.000$.

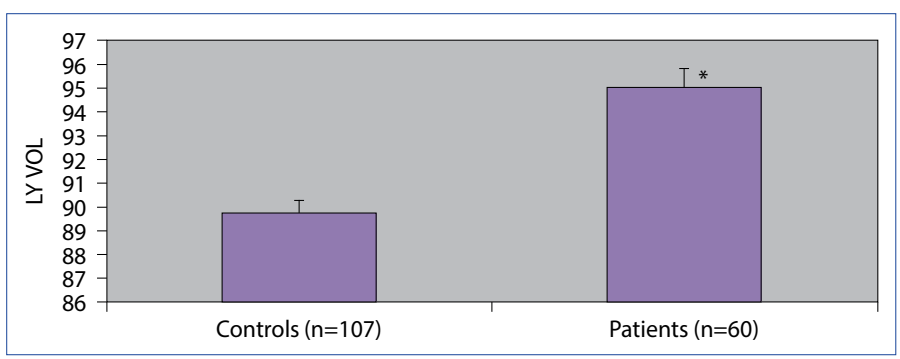

Figure 2. LY VOL in patients with multiple myeloma and control groups.

LYVOL: Lymphocyte volume, patients $95.05 \pm 6.08$ according to healthy subjects $89.78 \pm 4.92$, $\mathrm{p}=0.000$.

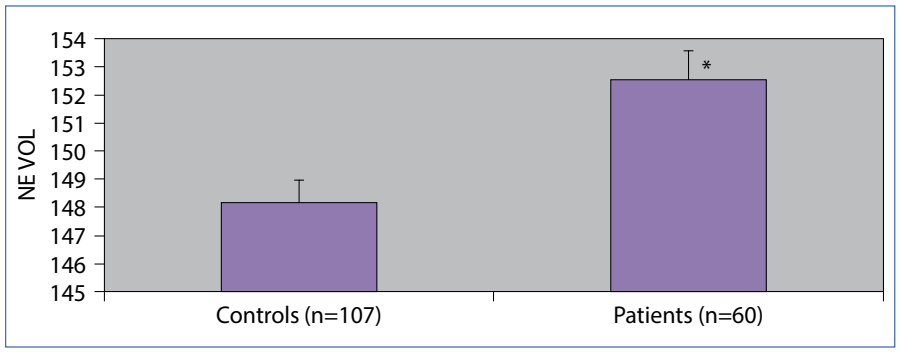

Figure 3. NE VOL in patients with multiple myeloma and control groups.

NE VOL: Neutrophil volume, patients $152.51 \pm 8.18$ according to healthy subjects $148.19 \pm 8.04, p=0.001$. 


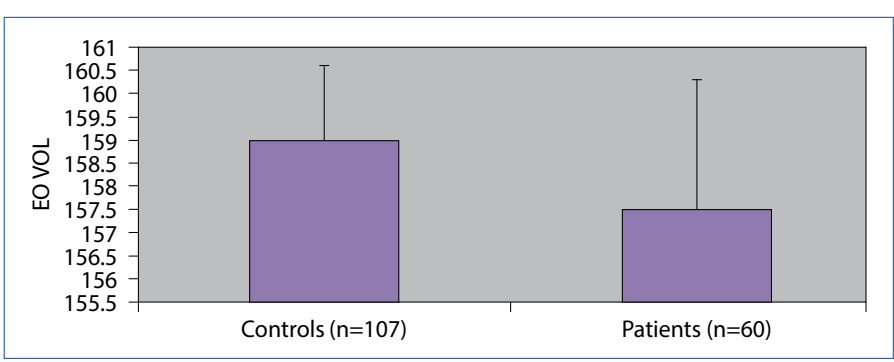

Figure 4. EO VOL in patients with multiple myeloma and control groups.

EO VOL: Eosinophils volume, patients $157.5 \pm 22.4$ according to healthy subjects $157 \pm 17.3$, $\mathrm{p}=0.953$.

\section{Discussion}

BM consists of white blood cells, red blood cells, plasma cells, lymphocytes and hemopoietic cells, phbroblasts, histiocytes/macrophages, fat cells and blood vessels, which contain many stages of mast cells [13]. In MM, cell cycle, plasma-cell differentiation, and DNA-damage repair pathways occur, and the immune system-related monocyte, neutrophil, eosinophil and lymphocyte levels are determined by evaluating these differences $[14,15]$. MM is primary events, secondary events, and disease caused by clonal heterogeneity $[16,17] . M M$ is a complex disease that arises from many genomic conditions when evaluated genetically [14]. MM has a molecular subtypes with many prognoses. These primary immunoglobulin heavy chain $(\mathrm{lgH})$ translocations are trisomy $(40 \%)$ or an $\mathrm{IgH}$ combination translocation and trisomy [18-20]. Factors that represent the disease biology of MM and affect the prognosis (age, performance status, molecular subtypes, comorbidities, disease stage) and exposure to mutagens (smoking or ultraviolet) in order to decide the treatment strategy (e.g., drug selection, duration and therapy) in patients light $[21,22]$. Monocytes are the largest leukocyte feature in peripheral blood [23]. Myeloid cells contain monocytes, granulocytes, macrophages and DC. Monocytes may differ from the monocyte derivative, DC or inflammatory macrophage [24]. The ability of MM cells to attract monocytes through various secreted factors can contribute to increased dysfunction of DC during illness [3]. With this differentiation feature, monocytes can modify and regulate immune responses according to their own advantage, as MM cells may affect the early stages of DC differentiation [16]. The spectrum of renal lesions in MM is heterogeneous, so myeloma nephropathy cannot be diagnosed at an early stage [7]. Although myeloid cells produced under these conditions are morphologically and phenotypically similar to neutrophils and monocytes, they have different genomic and biochemical structures and functions [11]. Eoz is anti-tumor functions in many malignancies [25]. In the human BM, $1-4 \%$ of the cellular compartment consists of eozs $[26,27]$. Morphological maturation of eozs precursors and myeloid cells occurs in the same way [13]. Neutrophils make up an average of $50-60 \%$ of leukocytes in the blood. Neutrophils are included in the bloodstream after being produced in the bone marrow. Generally, the neutrophil count does not increase in viral infections, but when there is a systemic infection or systemic inflammatory response, the number of neutrophils in the blood increases [28-31]. As a result, neutrophils play a role in assessing the susceptibility of cells to infection [11]. Lymphoid cells are located in the bone marrow [32]. BM lymphocytes increase when it comes to chronic lymphocytic leukemia [33]. T lymphocytes are involved in intercellular communication in the immune system and have an anti-tumor effect in patients with lymphoid malignancy $[34,35]$. B lymphocytes are responsible for humoral immunity. $T$ and $B$ lymphocytes work effectively among themselves and other cell types to stimulate immunity [35]. In addition, many studies show that the neutrophil-lymphocyte ratio (NLR) plays a role in predicting overall survival and prognosis in individuals with hematological cancer [36-40]. MDSC is absent in healthy individuals and occurs only in pathological events associated with cancer, chronic inflammation or stress [11]. There are many biochemical conditions that distinguish MDSC from controls. These include high arginine and iNOS expression and activity, high and persistent ROS (reactive oxygen species), such as myeloperoxidase, superoxide, hydroxyl peroxidase and peroxynitrite [41, 42]. Patients with MM with higher NLR are more likely to have a worse prognosis than patients with lower NLR [43]. Ramachandran et al. revealed that neutrophils affect the effectiveness of chemotherapy in patients with MM and thus the outcome of this disease [43]. Treatment of the disease is a long-term treatment that should be kept under control without consiredably impairing the quality of life of the individual throughout his life [44].

\section{Conclusion}

The present study aimed to evaluate a biomarker that is easily analyzed. This study indicated that monocyte, lymphocytes, neutrophil volume values except eosinophil volume might be used as a potentially prognostic biomarker in patients with Multiple myeloma.

Monocyte, lymphocyte and neutrophil volume levels are significant parameters that can be applied lower in cost.

Conflict of Interest: There is no conflict of interest.

Ethics Committee Approval: Selcuk University Medicine Faculty Local Ethics Committee Approval Number: 2020/60.

Financial Disclosure: There is no financial support.

Peer-review: Externally peer-reviewed.

Authorship Contributions: Concept - E.M., A.S.; Design - A.S., M.D.; Supervision - A.S., E.M.; Funding - A.S., M.D., E.M., H.K.; Materials - A.S., M.D.; Data collection \&/or processing - M.D., A.S.; Analysis and/or interpretation - M.D., A.S., E.M.; Literature search - E.M., H.K.; Writing - E.M., H.K., A.S.; Critical review - A.S., M.D., E.M. 


\section{References}

1. Kyle RA, Rajkumar SV. Multiple myeloma. N Engl J Med 2004;351(18):1860-73. [CrossRef]

2. WuT, Zhou J, Wang C, Wang B, Zhang S, Bai H. Bortezomib overcomes the negative prognostic impact of renal impairment in a newly diagnosed elderly patient with multiple myeloma: $\mathrm{A}$ case report. Oncol Lett 2017;14(6):7318-22. [CrossRef]

3. Freire-de-Lima L, Nardy AFFR, Ramos-Junior ES, Conde L, Santos Lemos J, da Fonseca LM, Lima JE, et al. Multiple Myeloma Cells Express Key Immunoregulatory Cytokines and Modulate the Monocyte Migratory Response. Front Med (Lausanne) 2017;4:92.

4. Ramachandran IR, Condamine T, Lin C, Herlihy SE, Garfall A, Vogl DT, et al. Bone marrow PMN-MDSCs and neutrophils are functionally similar in protection of multiple myeloma from chemotherapy. Cancer Lett 2016;371(1):117-24. [CrossRef]

5. Noonan K, Marchionni L, Anderson J, Pardoll D, Roodman $\mathrm{GD}$, Borrello I. A novel role of IL-17-producing lymphocytes in mediating lytic bone disease in multiple myeloma. Blood 2010;116(18):3554-63. [CrossRef]

6. Bladé J, Samson D, Reece D, Apperley J, Björkstrand B, Gahrton $\mathrm{G}$, et. Criteria for evaluating disease response and progression in patients with multiple myeloma treated by high-dose therapy and haemopoietic stem cell transplantation. Myeloma Subcommittee of the EBMT. European Group for Blood and Marrow Transplant. Br J Haematol 1998;102(5):1115-23. [CrossRef]

7. Liu, H, Xiong J, Zhang J, Zhang Y, Nie L, Wang Y, et al. Possible intrinsic association of anti-neutrophil cytoplasmic antibodyassociated vasculitis coexisting with multiple myeloma. Oncol Lett 2016;12(3):2084-86. [CrossRef]

8. Alexanian $\mathrm{R}$, Dimopoulos $\mathrm{M}$. The treatment of multiple myeloma. N Engl J Med 1994;330(7):484-9. [CrossRef]

9. Andersen $\mathrm{MH}$. Anti-regulatory $\mathrm{T}$ cells. Semin Immunopathol 2017;39(3):317-26. [CrossRef]

10. Ciocchini M, Arbelbide J, Musso CG. Monoclonal gammopathy of renal significance (MGRS): the characteristics and significance of a new meta-entity. Int Urol Nephrol 2017;49(12):2171-5. [CrossRef]

11. Gabrilovich DI. Myeloid-Derived Suppressor Cells. Cancer Immunol Res 2017;5(1):3-8. [CrossRef]

12. Wichert S, Pettersson $\AA$, Hellmark T, Johansson $\AA$, Hansson $M$. Bone marrow eosinophils in plasma cell disorders. Exp Hematol 2018;66:27-31.e5. [CrossRef]

13. Moonim MT, Porwit A. Normal bone barrow histology. In: Porwit A, McCullough J, Erber WN, editors. Blood and Bone Marrow Pathology. 2nd ed. NY: Elsevier; 2011. p. 45-62. [CrossRef]

14. Manier S, Salem KZ, Park J, Landau DA, Getz G, Ghobrial IM. Genomic complexity of multiple myeloma and its clinical implications. Nat Rev Clin Oncol 2017;14(2):100-13. [CrossRef]

15. Litman GW, Cannon JP, Dishaw LJ. Reconstructing immune phylogeny: new perspectives. Nat Rev Immunol 2005;5(11):866-79.

16. Walker BA, Wardell CP, Melchor L, Brioli A, Johnson DC, Kaiser $M F$, et al. Intraclonal heterogeneity is a critical early event in the development of myeloma and precedes the development of clinical symptoms. Leukemia 2014;28(2):384-90. [CrossRef]
17. Landau DA, Carter SL, Getz G, Wu CJ. Clonal evolution in hematological malignancies and therapeutic implications. Leukemia 2014;28(1):34-43. [CrossRef]

18. Vu T, Gonsalves W, Kumar S, Dispenzieri A, Lacy MQ, Buadi F, et al, Rajkumar SV. Characteristics of exceptional responders to lenalidomide-based therapy in multiple myeloma. Blood Cancer J 2015;5(10):e363. [CrossRef]

19. Pandey S, Rajkumar SV, Kapoor P, Ketterling RP, Lacy MQ, Gertz MA et al. Impact of FISH Abnormalities on Response to Lenalidomide in Patients with Multiple Myeloma. ASH Annu Meeting Abstr 2013;122:3210. [CrossRef]

20. Kumar S, Fonseca R, Ketterling RP, Dispenzieri A, Lacy MQ, Gertz $M A$, et al. Trisomies in multiple myeloma: impact on survival in patients with high-risk cytogenetics. Blood 2012;119(9):21005. [CrossRef]

21. Russell SJ, Rajkumar SV. Multiple myeloma and the road to personalised medicine. Lancet Oncol 2011;12(7):617-9. [CrossRef]

22. Palumbo A, Bringhen S, Mateos MV, Larocca A, Facon T, Kumar SK, et al. Geriatric assessment predicts survival and toxicities in elderly myeloma patients: an international myeloma working group report. Blood 2015;125(13):2068-2074. [CrossRef]

23. Wickramasinghe $S \mathrm{~N}$, Erber W. Normal blood cells. In: Porwit A, McCullough J, Erber WN, editors. Blood and Bone Marrow Pathology. 2nd ed. UK: Churchill Livingstone; 2011. p. 3-17.

24. Leone P, Berardi S, Frassanito MA, Ria R, De Re V, Cicco S, et al. Dendritic cells accumulate in the bone marrow of myeloma patients where they protect tumor plasma cells from CD8+ Tcell killing. Blood 2015;126(12):1443-51. [CrossRef]

25. Lotfi R, Lee JJ, Lotze MT. Eosinophilic granulocytes and damage-associated molecular pattern molecules (DAMPs): role in the inflammatory response within tumors. J Immunother 2007;30(1):16-28. [CrossRef]

26. Terstappen LW, Levin J. Bone marrow cell differential counts obtained by multidimensional flow cytometry. Blood Cells 1992;18(2):311-30; discussion 331-2.

27. Longo DL, Fauci AS, Kasper DL, Hauser SL, Jameson, JL, Loscalzo J, editors. Harrison's manual of medicine. New York: McGraw-Hill Medical; 2013.

28. May RC, Machesky LM. Phagocytosis and the actin cytoskeleton. Journal of Cell Science 2001;114(6):1061-77.

29. Salzet M, Tasiemski A, Cooper E. Innate immunity in lophotrochozoans: the annelids. Curr Pharm Des 2006;12(24):3043-50.

30. Zen K, Parkos CA. Leukocyte-epithelial interactions. Curr Opin Cell Biol 2003;15(5):557-64. [CrossRef]

31. Langermans JA, Hazenbos WL, van Furth R. Antimicrobial functions of mononuclear phagocytes. J Immunol Methods 1994; 174(1-2):185-94. [CrossRef]

32. Wolf E, Harms H, Winkler J, Reulbach U, Kirchner T, Niedobitek $\mathrm{G}$, et al. Terminal deoxynucleotidyl transferase-positive cells in trephine biopsies following bone marrow or peripheral stem cell transplantation reflect vigorous B-cell generation. Histopathology 2005;46(4):442-50. [CrossRef]

33. Bain BJ. Pathology of the marrow: General considerations and infections/reactive conditions. Blood and Bone Marrow Pathology E-Book. 2011. p. 79. [CrossRef] 
34. Wilhelm M, Kunzmann V, Eckstein S, Reimer $P$, Weissinger $\mathrm{F}$, Ruediger $\mathrm{T}$, et al. Gammadelta $\mathrm{T}$ cells for immune therapy of patients with lymphoid malignancies. Blood 2003;102(1):200-6. [CrossRef]

35. Pancer Z, Cooper MD. The evolution of adaptive immunity. Annu Rev Immunol 2006;24:497-518. [CrossRef]

36. Polterauer S, Grimm C, Seebacher V, Rahhal J, Tempfer C, Reinthaller $A$, et al. The inflammation-based Glasgow Prognostic Score predicts survival in patients with cervical cancer. Int J Gynecol Cancer 2010;20(6):1052-7. [CrossRef]

37. Pinato DJ, Stebbing J, Ishizuka M, Khan SA, Wasan HS, North $B V$, et al. A novel and validated prognostic index in hepatocellular carcinoma: the inflammation based index (IBI). J Hepatol 2012;57(5):1013-20. [CrossRef]

38. Proctor MJ, Horgan PG, Talwar D, Fletcher CD, Morrison DS, McMillan DC. Optimization of the systemic inflammationbased Glasgow prognostic score: a Glasgow Inflammation Outcome Study. Cancer 2013;119(12):2325-32. [CrossRef]

39. Duffy BK, Gurm HS, Rajagopal V, Gupta R, Ellis SG, Bhatt DL. Usefulness of an elevated neutrophil to lymphocyte ratio in predicting long-term mortality after percutaneous coronary intervention. Am J Cardiol 2006;97(7):993-6. [CrossRef]

40. Tsujimura A, Kawamura N, Ichimura T, Honda K, Ishiko O, Ogita $\mathrm{S}$. Telomerase activity in needle biopsied uterine myoma-like tumors: differential diagnosis between uterine sarcomas and leiomyomas. Int J Oncol 2002;20(2):361-5. [CrossRef]

41. Bronte V, Brandau S, Chen SH, Colombo MP, Frey AB, Greten TF, et al. Recommendations for myeloid-derived suppressor cell nomenclature and characterization standards. Nat Commun 2016;7:12150. [CrossRef]

42. Nagaraj S, Gupta K, Pisarev V, Kinarsky L, Sherman S, Kang L, et al. Altered recognition of antigen is a mechanism of CD8+ T cell tolerance in cancer. Nat Med 2007;13(7):828-35. [CrossRef]

43. Mu S, Ai L, Fan F, Sun C, Hu Y. Prognostic role of neutrophillymphocyte ratio in multiple myeloma: a dose-response meta-analysis. Onco Targets Ther 2018;11:499-507. [CrossRef]

44. McCarthy PL, Owzar K, Hofmeister CC, Hurd DD, Hassoun $H$, Richardson PG, et al. Lenalidomide after stemcell transplantation for multiple myeloma. $\mathrm{N}$ Engl J Med 2012;366(19):1770-81. [CrossRef] 